\title{
Nitrogen isotope dynamics and fractionation during sedimentary denitrification in Boknis Eck, Baltic Sea
}

\author{
K. Dähnke ${ }^{1,2}$ and B. Thamdrup ${ }^{1}$ \\ ${ }^{1}$ Nordic Center for Earth Evolution, University of Southern Denmark, 6550 Odense, Denmark \\ ${ }^{2}$ Helmholtz-Zentrum Geesthacht, Institute for Coastal Research, Max-Planck-Str. 1, 21502 Geesthacht, Germany \\ Correspondence to: K. Dähnke (kirstin.daehnke@hzg.de)
}

Received: 19 December 2012 - Published in Biogeosciences Discuss.: 10 January 2013

Revised: 26 March 2013 - Accepted: 11 April 2013 - Published: 7 May 2013

\begin{abstract}
The global marine nitrogen cycle is constrained by nitrogen fixation as a source of reactive nitrogen, and denitrification or anammox on the sink side. These processes with their respective isotope effects set the marine nitrate ${ }^{15} \mathrm{~N}$ isotope value $\left(\delta^{15} \mathrm{~N}\right)$ to a relatively constant average of $5 \%$. This value can be used to better assess the magnitude of these sources and sink terms, but the underlying assumption is that sedimentary denitrification and anammox, processes responsible for approximately one-third of global nitrogen removal, have little to no isotope effect on nitrate in the water column.

We investigated the isotope fractionation in sediment incubations, measuring net denitrification and nitrogen and oxygen stable isotope fractionation in surface sediments from the coastal Baltic Sea (Boknis Eck, northern Germany), a site with seasonal hypoxia and dynamic nitrogen turnover.

Sediment denitrification was fast, and regardless of current paradigms assuming little fractionation during sediment denitrification, we measured fractionation factors of $18.9 \%$ or nitrogen and $15.8 \%$ for oxygen in nitrate. While the input of nitrate to the water column remains speculative, these results challenge the current view of fractionation during sedimentary denitrification and imply that nitrogen budget calculations may need to consider this variability, as both preferential uptake of light nitrate and release of the remaining heavy fraction can significantly alter water column nitrate isotope values at the sediment-water interface.
\end{abstract}

\section{Introduction}

Reactive nitrogen in the world's oceans plays a key role in governing biological productivity in the water column. The largest pool of nitrogen in the biosphere, Air- $\mathrm{N}_{2}$, is unavailable to most organisms, and is only introduced to marine systems by nitrogen fixation. Hence, the marine nitrogen cycle in the open ocean is driven by the interplay of this primary source of reactive nitrogen and its two major sinks, anammox and denitrification, which both create $\mathrm{N}_{2}$ and remove reactive nitrogen from the marine system (e.g., Voss and Montoya, 2009; Altabet, 2007; Galloway et al., 2004).

Stable isotope budgets greatly aid in assessing the turnover of this bioavailable nitrogen on both local and global scales (Brandes and Devol, 2002; Altabet et al., 2002). An important prerequisite when using stable nitrogen isotopes to define the global nitrogen budget is that the isotope fractionation factors of each of these processes are adequately assessed and validated. Nitrate, the predominant form of dissolved nitrogen in the open ocean, has an average stable isotope value of approximately $5 \%$ o (e.g., Sigman et al., 2000) (Fig. 1).

This average value is determined by the interplay of nitrogen fixation on the one and denitrification (here referring to the microbial respiration of nitrate via $\mathrm{N}_{2} \mathrm{O}$ to $\mathrm{N}_{2}$ ) and anammox (bacterial comproportionation of nitrite and ammonium to $\mathrm{N}_{2}$ ) on the other side. Most biological turnover processes discriminate the heavier versus the lighter isotope, leading to a slightly faster turnover of light ${ }^{14} \mathrm{~N}$ in comparison to ${ }^{15} \mathrm{~N}$. Dinitrogen fixation has a small isotope effect (Delwiche and Steyn, 1970), and forms light organic matter with an isotope value of $\sim-2$ to $+2 \%$, which, upon complete remineralization and oxidation, lowers the average $\delta^{15} \mathrm{~N}_{\mathrm{NO}_{3}}$ value in the open ocean (e.g., Montoya et al., 2002; Emeis et al., 2010). On the other hand, denitrification in anoxic water bodies has a large isotope effect of $\sim-25 \%$ (e.g., Brandes et al., 1998; 


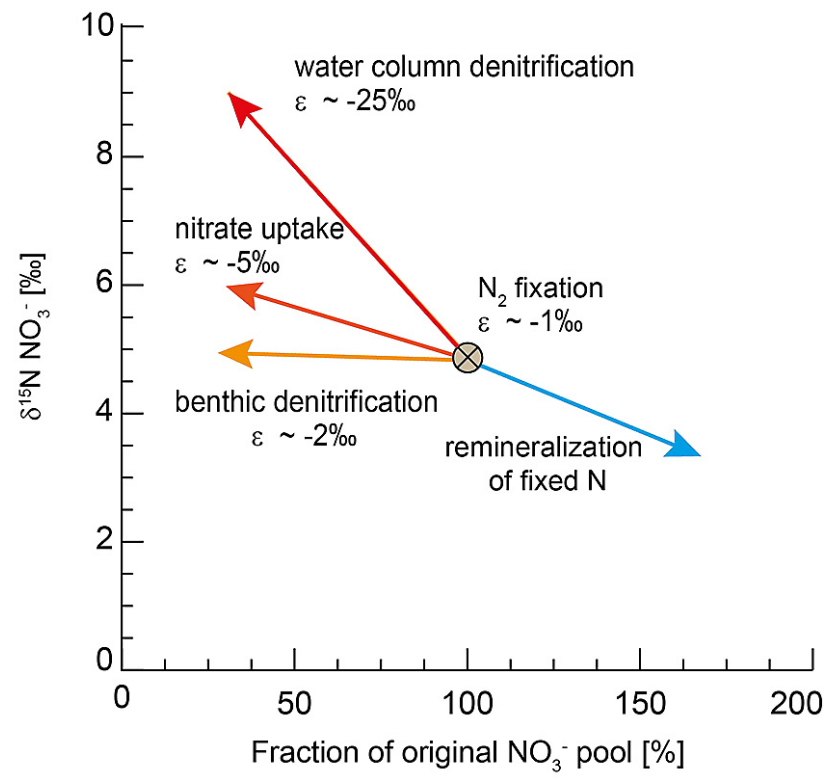

Fig. 1. Isotopic changes during nitrate turnover in the open ocean. After Gruber (2004).

Voss et al. 2001). To date, little is known about the isotope fractionation of anammox in the water column, but it is generally assumed that anammox, just like denitrification, coincides with considerable, possibly similar, isotope fractionation (Naqvi et al., 2006).

However, barring the uncertainty regarding the isotope effect of anammox in the water column, another challenge of the isotope approach is that the isotope effect also depends on environmental conditions. Both denitrification and anammox also occur in marine sediments, with an estimated sedimentary contribution of $\sim 44 \%$ to total global denitrification (Seitzinger et al., 2006). The apparent isotope fractionation in sedimentary denitrification is commonly believed to be much less pronounced than in the water column (e.g., Sigman et al., 2009; Lehmann et al., 2003). Studies in marine deep sea sediments have shown that sedimentary denitrification leads to enrichment of pore water nitrate, but this nitrate does not reach the water column, thus leaving little to no isotopic imprint on the water column nitrate inventory (Lehmann et al., 2007).

Studies addressing this issue, though, addressed deep-sea sediments, and the main objective of the present study was to test this hypothesis in more reactive coastal sediments, in order to further elucidate the dynamics of sedimentary denitrification. Specifically, we wanted to investigate the intrinsic fractionation effect in sediments, and aimed to unravel isotope fractionation of both nitrate and nitrite reduction.

\section{Study site}

The time series station Boknis Eck $\left(54^{\circ} 31^{\prime} \mathrm{N}, 10^{\circ} 02^{\prime} \mathrm{E}\right)$ is located in the coastal Baltic Sea, at the entrance of Eckernförde
Bay (northern Germany). Despite its proximity to the coast, discharge from land is negligible at this site, and the hydrographic setting is typical for the southwestern Baltic Sea (Bange et al., 2011). Due to the mixing of saline North Sea water masses with fresher Baltic Sea water, the station experiences a seasonal stratification, coinciding with pronounced hypoxia and occasional anoxia in bottom waters.

Sediments in Boknis Eck contain 4-5 wt \% organic matter (Whiticar, 2002; Treude et al., 2005), making it a likely site for heterotrophic processes like denitrification. The sedimentation rate is high between 0.3 and $1 \mathrm{~cm} \mathrm{yr}^{-1}$ (Nittrouer et al., 1998). The study site is characterized by muddy, very fluffy sediments, with porosities of up to 0.92 in the upper 3 to $4 \mathrm{~cm}$ (Treude et al., 2005; Orsi et al., 1996).

\section{Materials and methods}

\subsection{Sampling and sediment incubation}

Samples were taken on 26 April 2010 at the Boknis Eck Time Series study site with the R/V Alkor. As part of the routine monthly monitoring at this site, water samples were taken in $5 \mathrm{~m}$ intervals and analyzed, among other parameters, for $\mathrm{O}_{2}$ and DIN (dissolved inorganic nitrogen) concentration using standard colorimetric procedures (Grasshoff et al., 1999). Subsamples of these water column samples were filtered $\left(\mathrm{GF} / \mathrm{F}\right.$, precombusted at $450^{\circ} \mathrm{C}$ for $\left.5 \mathrm{~h}\right)$ and stored frozen $\left(-18^{\circ} \mathrm{C}\right)$ for later isotope analysis, which was possible in samples with $\left[\mathrm{NO}_{3}^{-}\right]>1 \mu \mathrm{M}$.

Additionally to the routine water sampling, sediment samples were taken the same day with a multicorer with $10 \mathrm{~cm}$ diameter core liners. Water depth at the station was $27.8 \mathrm{~m}$, bottom water temperature $5.5^{\circ} \mathrm{C}$, and salinity in the overlying water 20.5.

Overlying water was removed from the cores, and the oxidized $\sim 0.5 \mathrm{~cm}$-thick top layer of sediment (the boundary of which was indicated by the appearance of black iron sulfides in subsurface layers) was scraped off and transferred into a beaker for subsequent use in the sediment incubations. This surface sediment was carefully homogenized and continually stirred while $180 \mathrm{ml}$ were aliquoted into each of two oxygen-impermeable polypropylene bags. After a preincubation (overnight at $6.7^{\circ} \mathrm{C}$ ) to remove all ambient nitrate, sediment in these bags was spiked with a $25 \mathrm{mM}$ nitrate solution $\left(\delta^{15} \mathrm{~N}=0.1 \%\right.$ o, $\delta^{18} \mathrm{O}=24.2 \%$ ) , aiming for a final concentration of $\sim 120 \mu \mathrm{M}$. The incubation bags were then immediately closed and homogenized thoroughly to ensure even nitrate distribution.

During the incubation, the sediment incubation bags were kept cool in insulated boxes. At distinct time intervals, $30 \mathrm{~mL}$ of homogenized sediment were transferred into $50 \mathrm{~mL} \mathrm{Fal-}$ con tubes. Care was taken to not let any ambient air enter the bags, which were closed again immediately after sampling. The samples were immediately centrifuged $(7 \mathrm{~min}, 4400 \mathrm{~g}$, 
$4{ }^{\circ} \mathrm{C}$ ) to extract pore water from the slurries. Overlying water was filtered (GFF) and frozen immediately for later on-shore analysis of nutrient concentration and nitrogen isotope values.

\subsection{Nutrient analysis}

Nutrients from bag incubations were analyzed manually. Nitrite was analyzed using standard colorimetric methods (Grasshoff et al., 1999). Nitrate + nitrite concentrations were determined by vanadium chloride reduction and subsequent $\mathrm{NO}_{\mathrm{x}}$ analysis $\left(\mathrm{NO}_{\mathrm{x}}\right.$ analyzer model $42 \mathrm{c}$; Thermo Environmental Instruments, Inc., Franklin, MA), based on the method by Braman and Hendrix (1989). Nitrate concentration was calculated by difference. Ammonium concentrations were measured manually in a flow-through system where ammonium concentration was detected via changes in conductivity, following the method of Hall and Aller (1992).

\subsection{Nitrate isotope analysis}

$\delta^{15} \mathrm{~N}$ and $\delta^{18} \mathrm{O}$ of nitrate were determined with the denitrifier method (Sigman et al., 2001; Casciotti et al., 2002). In brief, water samples were injected into a suspension of Pseudomonas aureofaciens (ATCC\#13985) for combined analysis of $\delta^{15} \mathrm{~N}$ and $\delta^{18} \mathrm{O}$. Nitrate and nitrite in water samples are quantitatively converted to $\mathrm{N}_{2} \mathrm{O}$ gas, which is stripped from the vials by purging with helium, concentrated and purified on a GasBench II and analyzed on a Delta V mass spectrometer (Thermo Finnigan). We performed replicate measurements, and two international standards (IAEA-N3, $\delta^{15} \mathrm{~N}=4.7 \% o, \delta^{18} \mathrm{O}=25.6 \%$ ) and USGS $34\left(\delta^{15} \mathrm{~N}=-1.8 \%\right.$ o, $\delta^{18} \mathrm{O}=-27.9 \%$, Böhlke et al., 2003) were measured with each batch of samples. To correct for exchange with oxygen atoms from water, we applied a bracketing correction (Sigman et al., 2009). For further quality assurance of the results, we used an internal potassium nitrate standard that was measured with each batch of samples.

$\delta^{15} \mathrm{~N}$ values showed reproducibility within the standard deviation of measurements. The standard deviation for international and in-house standards was $0.2 \%$ for $\delta^{15} \mathrm{~N}$ and $0.5 \%$ for $\delta^{18} \mathrm{O}(n=5)$; deviations for replicate samples were in the same range or better.

Furthermore, the oxygen and nitrogen isotope values were corrected for the contribution of nitrite according to the following formula:

$\delta_{\mathrm{NO}_{3}}=\frac{\delta_{\text {bulk }} \times\left(c_{\mathrm{NO}_{3}}+c_{\mathrm{NO}_{2}}\right)-\delta_{\mathrm{NO}_{2}} \times c_{\mathrm{NO}_{2}}}{c_{\mathrm{NO}_{3}}}$,

where $\delta$ and $c$ are isotope values and concentration of the individual components, respectively.

\subsection{Nitrite isotope analysis}

$\delta^{15} \mathrm{~N}_{\mathrm{NO}_{2}}$ was analyzed according to Böhlke et al. (2007). In brief, nitrite is selectively reduced to $\mathrm{N}_{2} \mathrm{O}$ by
Stenotrophomonas nitritireducens (supplied by Nils Risgaard-Petersen). Further extraction procedures are the same as for nitrate isotope determination. For calibration, we used two in-house nitrite standards with known $\delta^{15} \mathrm{~N}_{\mathrm{NO}_{2}}$ values of $-82.3 \%$ o (NO2-HZG1) and $-27.6 \%$ o (NO2-HZG2) vs. Air- $\mathrm{N}_{2}$, determined independently with an elemental analyzer (Flash EA 1112) coupled to an isotope ratio mass spectrometer (Thermo Finnigan Delta Plus XP).

For $\delta{ }^{15} \mathrm{~N}_{\mathrm{NO}_{2}}$, the standard deviation of our measurements was better than $0.6 \% o(n=5)$. While this method allows for a simultaneous determination of oxygen isotopes in nitrite (standard deviation was below $0.5 \%$ in our analyses), nitrite oxygen exchanges with ambient water within days to weeks (Casciotti et al., 2007; Böhlke et al., 2007) and thus offers no further information on biogeochemical processes in the experiment. Nevertheless, $\delta^{18} \mathrm{O}_{\mathrm{NO}_{2}}$ values are indispensable; as they are needed for correction of nitrate isotope data (see above).

\section{Results}

\subsection{Water column properties}

DIN and $\mathrm{O}_{2}$ concentrations in the water column were measured as part of the continuous monitoring at Boknis Eck, and results have been published elsewhere (Bange et al., 2011). Here, they are only mentioned briefly where they relate to this investigation.

At the time of sampling, the entire water column was oxygenated, with minimum $\left[\mathrm{O}_{2}\right]$ of $232.9 \mu \mathrm{M}$ in $25 \mathrm{~m}$ depth. DIN concentrations increased with water depth (Fig. 2), with ammonium and nitrate concentration rising above $1 \mu \mathrm{M}$ below $15 \mathrm{~m}$ water depth. Nitrate and nitrite concentrations in bottom water were 2.2 and $0.17 \mu \mathrm{M}$, respectively, where $\left[\mathrm{NH}_{4}^{+}\right]$ reached $3.5 \mu \mathrm{M}$.

We measured nitrate isotopes in bottom water (25 $\mathrm{m}$ depth) and found isotope values of $7.7 \%$ and $13.5 \%$ in $\delta^{15} \mathrm{~N}_{\mathrm{NO}_{3}}$ and $\delta^{18} \mathrm{O}_{\mathrm{NO}_{3}}$, respectively (data not shown in plots); lower nitrate concentrations from surface water yielded unacceptable standard deviations.

\subsection{DIN concentrations and isotopes in sediment incubations}

Over the course of the incubations, nitrate concentrations decreased at a rate of $\sim 87 \mathrm{nmol} \mathrm{cm}{ }^{-3} \mathrm{~h}^{-1}$ (Fig. 3a), slowing slightly towards the end of the incubation. The parallel assays were very well comparable with ammonium concentrations initially at $75 \mu \mathrm{M}$ (average of the two incubations), increasing steadily to $89.5 \mu \mathrm{M}$ after $90 \mathrm{~min}$. This corresponds to an ammonium release of $\sim 11 \mathrm{nmol} \mathrm{N} \mathrm{cm}^{-3} \mathrm{~h}^{-1}$. Nitrite concentrations remained stable at $2 \pm 0.1 \mu \mathrm{M}$ throughout the entire experiment.

Both nitrite and nitrate isotope signatures increased over time as nitrate turnover proceeded (Fig. 3b). Initial nitrate 


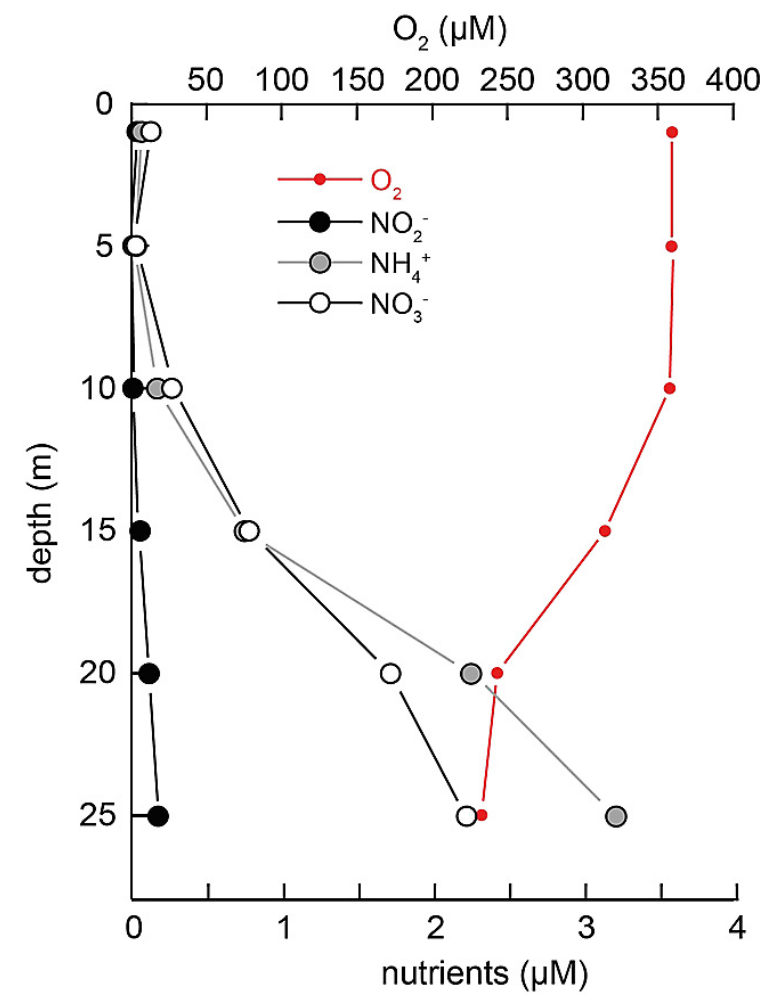

Fig. 2. Nutrient and $\mathrm{O}_{2}$ concentration in the water column in April 2010. Data were raised as part of the routine monitoring at Boknis Eck (Bange et al., 2011).

isotope signatures in the incubations were close to that of the added substrate, with average values of $0.9 \%$ and $25.3 \%$ o for $\delta^{15} \mathrm{~N}$ and $\delta^{18} \mathrm{O}$ in nitrate, respectively. Within $90 \mathrm{~min}$, $\delta^{15} \mathrm{~N}_{\mathrm{NO}_{3}}$ increased on average by $\sim 49 \%$ o to final values of 52.1 and $47.8 \%$ in the parallel incubations, and $\delta^{18} \mathrm{O}_{\mathrm{NO}_{3}}$ increased by $\sim 41 \%$ o to 70.0 and $62.1 \%$.

Nitrite isotope data are not as consistent between the parallel incubations, with initial values (i.e., 3 to 4 min after substrate addition) varying between $-14.7 \%$ and $-0.9 \%$ for $\delta^{15} \mathrm{~N}$. After $8 \min (t 1), \delta^{15} \mathrm{~N}_{\mathrm{NO}_{2}}$ values in the incubations were again comparable at an average of $-12.7 \%$, increasing steadily with time to $35.4 \%$ (mean of both incubations) at the end of the experiment. Overall, $\delta^{15} \mathrm{~N}_{\mathrm{NO}_{2}}$ closely followed $\delta^{15} \mathrm{~N}_{\mathrm{NO}_{3}}$ throughout the experiment (Fig. 3b).

Isotope effects for oxygen and nitrogen in nitrate were derived from the linearization of Rayleigh model plots, according to Mariotti et al. (1981):

$\delta^{15} \mathrm{~N}=\delta^{15} \mathrm{~N}_{\text {initial }}+{ }^{15} \varepsilon(\ln (f))$,

where $f$ denotes the fraction of the initial substrate, i.e., nitrate, added.

We found fractionation factors of $\varepsilon^{15}=18.9 \pm 0.9 \%$ and $\varepsilon^{18}=15.8 \pm 0.7 \%$ o for nitrate nitrogen and oxygen, respectively and saw no indications of a change in the slopes as nitrate was depleted (Fig. 4). As there is no net change in nitrite concentration over the course of the incubation, the isotope effect of nitrite isotope values was calculated based on the decrease of nitrate concentrations. The computed isotope effect is comparable to that of nitrogen in nitrate, $18.0 \pm 1.4 \%$ o (Fig. 4). The offset between nitrate and nitrite isotope values is nearly constant at $\sim 14 \%$ o throughout most of the experiment, with almost identical nitrate and nitrite isotope values only at the very beginning of one incubation assay.

\section{Discussion}

\subsection{Nitrate consumption in sediment incubations}

The nitrate concentration in the anoxic incubations decreased rapidly, by an average of $140 \mu \mathrm{M}$ over 90 min with no accumulation of nitrite. Potential processes for nitrate and nitrite reduction are anammox, denitrification and dissimilatory nitrate reduction to ammonium (DNRA). Anammox was likely not of any importance. We did not detect any anaerobic oxidation after addition of nitrate and ${ }^{15} \mathrm{~N}$-labeled ammonium to homogenized sediment samples from this site in October 2009 (unpublished results), consistent with observations that this process typically contributes less than $10 \%$ to $\mathrm{N}_{2}$ production or $5 \%$ of nitrite reduction in organic-rich coastal sediments (Thamdrup and Dalsgard, 2002; Thamdrup, 2012). Furthermore, the rate of nitrate + nitrite consumption was 5fold higher than the highest rate of anammox so far reported from marine sediments (Trimmer and Engström, 2011).

The low ratio of ammonium accumulation to nitrate reduction also constrains DNRA to a minor potential role. Assuming an adsorption coefficient of 1.3 for ammonium as in other coastal marine sediments (Berner, 1980; Mackin and Aller, 1984), the accumulation of $14.5 \mu \mathrm{M}$ ammonium in the pore water corresponds to the release of $(14.5 \cdot[1+1.3]=) 33 \mu \mathrm{M}$ ammonium in total, or $24 \%$ of the nitrate reduction, as a maximum contribution of DNRA. Ammonium also accumulates due to mineralization, and the mineralization of detritus of Redfieldian composition coupled to the denitrification of $140 \mu \mathrm{M}$ nitrate would release $(140 \cdot 5 \mathrm{C} / 4 \mathrm{~N} \cdot 16 / 106=) 26 \mu \mathrm{M}$ ammonium. Thus, most of the ammonium accumulation was likely sourced by mineralization. We thus conclude that nitrate removal in the homogenized sediment from Boknis Eck is strongly dominated by rapid denitrification.

This nitrate removal via heterotrophic denitrification occurred at a rate of $\sim 87 \mathrm{nmol} \mathrm{cm}{ }^{-3} \mathrm{~h}^{-1}$, which is in the range of other shallow coastal sediments (Dalsgaard et al., 2005; Trimmer and Engström, 2011 and references therein). For example, Trimmer at al. (2003) found nitrate removal rates between 40 and $110 \mathrm{nmol} \mathrm{cm}^{-3} \mathrm{~h}^{-1}$ in sediments from the outer reach of the nitrate-rich Thames estuary, which agrees well with our data from Eckernförde Bay. 

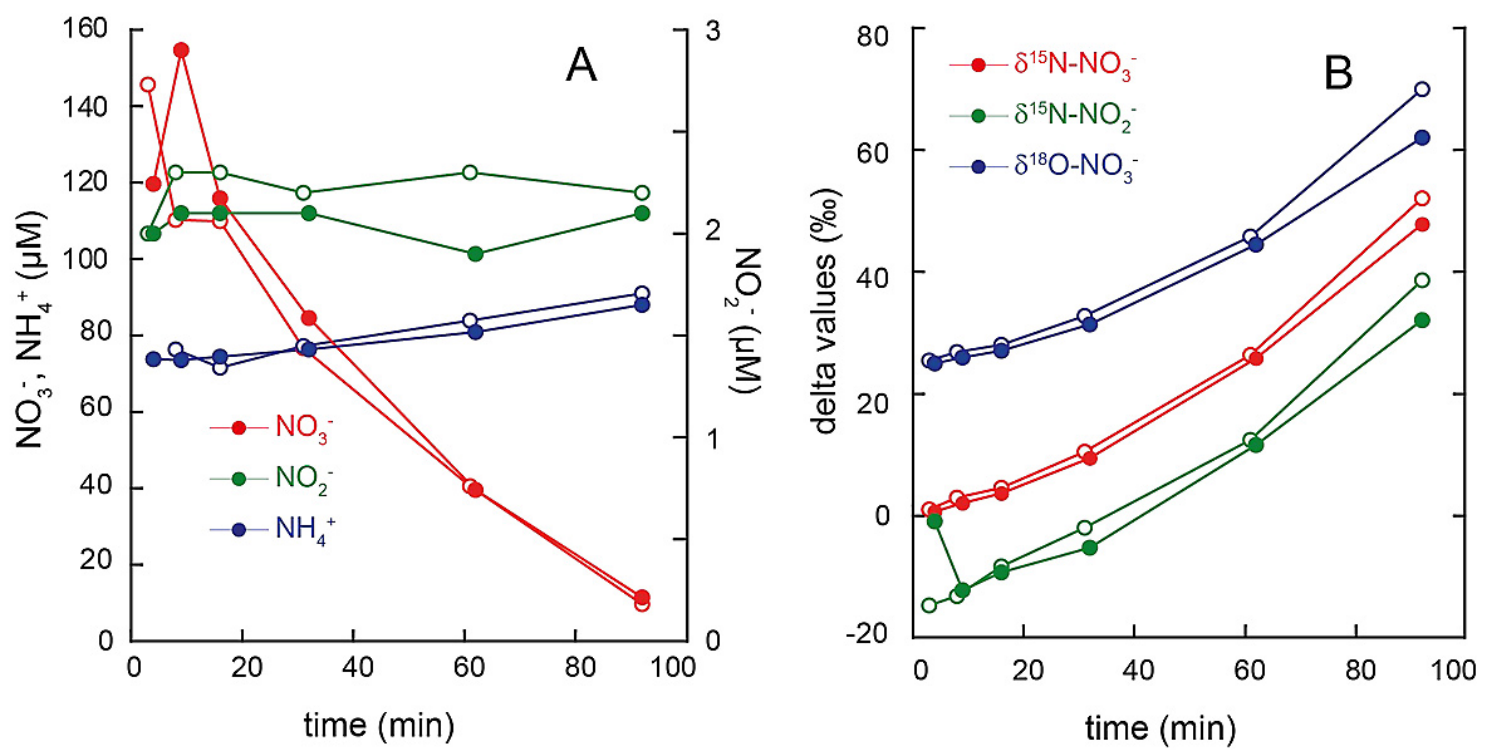

Fig. 3. Changes (A) in DIN concentration and (B) nitrate and nitrite isotopes over time in two parallel sediment incubations (open and filled symbols).

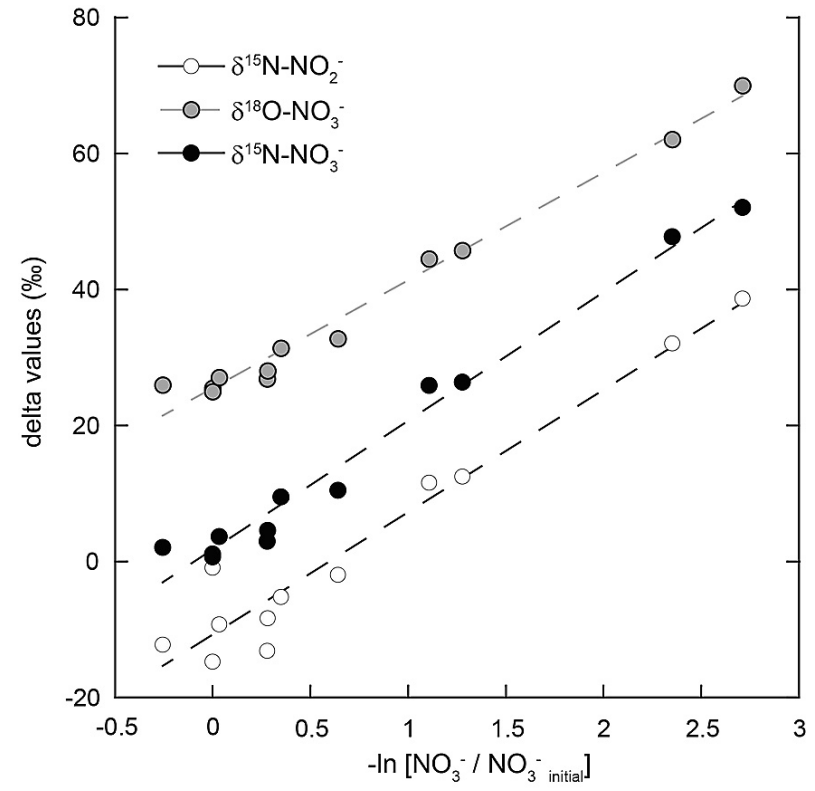

Fig. 4. Rayleigh plots of the change in the $\mathrm{N}$ isotopic composition of nitrate $\left(\delta^{15} \mathrm{~N}\right.$ and $\left.\delta^{18} \mathrm{O}\right)$ and nitrite $\left(\delta^{15} \mathrm{~N}\right)$ as a function of the natural logarithm of the remaining nitrate fraction.

\subsection{The nature and isotope effect of nitrate reduction}

Water column denitrification significantly favors light nitrogen isotopes over heavier ones, resulting in a fractionation of $\sim 25 \%$ o for both nitrogen and oxygen atoms in nitrate in the marine environment (e.g., Brandes et al., 1998; Granger et al., 2008; Voss et al., 2001). In sediments, the reaction rate is limited by diffusion, and, accordingly, this fraction- ation effect is not visible in the apparent fractionation during sedimentary denitrification (e.g., Brandes and Devol, 2002). Recent studies (Lehmann et al., 2007; Alkhatib et al., 2012) propose that the intrinsic isotope effect of denitrification in sediments is comparable to that of water column denitrification.

Our experiment yields a fractionation factor of $\varepsilon^{15}=18.9 \%$, which is on the low end of isotope effects reported for water column denitrification in the ocean's oxygen minimum zones (Voss et al., 2001; Naqvi et al., 1998), and comparable to that measured in cultures of different denitrifying bacteria (Granger et al., 2008). It also agrees well with the range estimated from modeling of pore water distributions in deep-sea sediments (11-30\%o; Lehman et al., 2007), thus supporting that intrinsic fractionation factors in marine sediments are within this range. We also found considerable enrichment in $\delta^{18} \mathrm{O}_{\mathrm{NO}_{3}}$, with a fractionation factor of $15.8 \%$ o. Both in culture (Granger et al., 2008) and in nature (e.g., Sigman et al., 2005), denitrification follows a fractionation of $1: 1$ for $\varepsilon^{18} / \varepsilon^{15}$. To date, $\delta^{18} \mathrm{O}$ fractionation during sediment denitrification has received little attention, mainly due to analytical limitations, but the general assumption is that the intrinsic isotope effects for both elements are comparable to that of water column denitrification, while restricted to the sediment pore water only (Wankel et al., 2009). In a recent dual nitrate isotope study on sediment denitrification off the coast of California, Prokopenko et al. (2011) indeed measured a $\varepsilon^{18} / \varepsilon^{15}$ ratio of $1: 1$ for nitrate removal. The relative enrichment of $\delta^{18} \mathrm{O}_{\mathrm{NO}_{3}}$ versus $\delta^{15} \mathrm{~N}_{\mathrm{NO}_{3}}$ in our experiment is plotted on a significantly ( $\alpha=0.05$ ) lower slope of $\sim 0.83: 1$ (Fig. 5). Despite its proximity to the coast, Eckernförde Bay is 


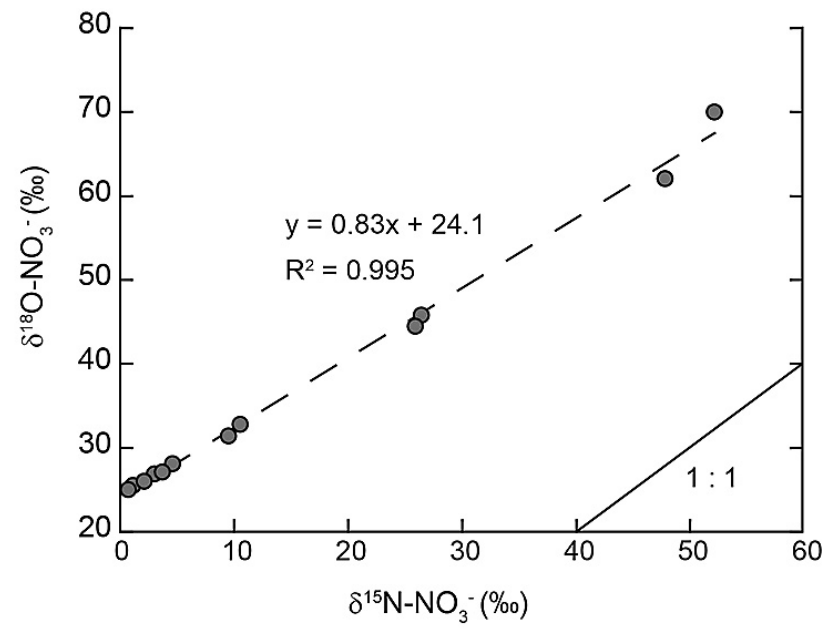

Fig. 5. Plot of $\delta^{15} \mathrm{~N}_{\mathrm{NO}_{3}}$ vs. $\delta^{18} \mathrm{O}_{\mathrm{NO}_{3}}$ from sediment incubations. $1: 1$ line is shown for reference.

governed by marine influences and would thus be expected to follow the $1: 1$ ratio.

Different mechanisms could drive the $\varepsilon^{18} / \varepsilon^{15}$ ratio off the expected $1: 1$ ratio. In freshwater soils, aquifers and water bodies, $\varepsilon^{18} / \varepsilon^{15}$ values were $\sim 0.6$ during denitrification (Lehmann et al., 2003). The reason for this difference between marine and freshwater environments is still under debate. Granger et al. (2008) identified deviant $\varepsilon^{18} / \varepsilon^{15}$ values between different enzymes that are involved in nitrate reduction: activity of the periplasmic nitrate reductase (Nap) in Rhodobacter sphaeroides resulted in an $\varepsilon^{18} / \varepsilon^{15}$ value of $\sim 0.6$, whereas the membrane-bound respiratory nitrate reductase (Nar) in classical heterotrophic denitrifiers produced $\varepsilon^{18} / \varepsilon^{15}$ values of $\sim 1$. The authors conclude that an additional expression of Nap in classical denitrifiers can lead to deviations in $\varepsilon^{18} / \varepsilon^{15}$ from the $1: 1$ ratio.

Although Nap is not part of respiratory nitrate reduction during denitrification, these findings illustrate that different nitrate reductase enzymes can lead to variation in isotope fractionation of oxygen and nitrogen during denitrification. Accordingly, variations in enzyme equipment between different strains of denitrifiers, in marine and freshwater communities (Wunderlich et al., 2012), still seem a likely explanation of the variant $\varepsilon^{18} / \varepsilon^{15}$ ratio.

Eckernförde Bay, while representative of the situation in the western Baltic Sea, is less saline $(\sim 14-24$, Treude et al., 2005) than the open ocean, so we hypothesize that the $\varepsilon^{18} / \varepsilon^{15}$ value in Eckernförde Bay may be a legacy of its intermediate status between these different environments. If this hypothesis holds, similar relationships between $\delta^{15} \mathrm{~N}_{\mathrm{NO}_{3}}$ and $\delta^{18} \mathrm{O}_{\mathrm{NO}_{3}}$ should be generated during water column denitrification in enclosed seas like the Baltic or Black Sea, but to the best of our knowledge, there are no published studies addressing this issue. Our data accordingly add more evidence to the occurrence of what Granger et al. (2008) referred to as "the freshwater conundrum", but nitrate isotope data alone cannot help us to solve questions regarding the underlying mechanisms for this difference between marine and fresh waters. The influence of salinity on isotope effects, both in itself and as a proxy of marine conditions, will need to be analyzed in further detail, if isotope trends are to be used as proxies of nitrogen turnover in coastal waters.

\subsection{Implications for water column nitrate composition}

Our incubation assay, while well-fitted to derive the intrinsic isotope effects, does not represent natural conditions because of the disruption of natural biogeochemical gradients. Consequently, our experimental setup precludes the extrapolation of potential flux of enriched nitrate from the sediment to the water column. Nevertheless, the water column profile of DIN concentration in April (Fig. 2) shows elevated DIN concentration near the sediment surface, with relatively heavy isotope signatures of $7.7 \%$ and $13.5 \%$ in $\delta^{15} \mathrm{~N}_{\mathrm{NO}_{3}}$ and $\delta^{18} \mathrm{O}_{\mathrm{NO}_{3}}$, respectively. Two mechanisms for these elevated nitrate isotope values in bottom waters shall be explored. One possibility is nitrification of ammonium at the very surface of the sediment; the other is an impact of preferential use of light nitrate in sedimentary denitrification, i.e., an impact of fractionation during sedimentary denitrification. Nitrification in surface sediments would require ammonium as a substrate, and sediments at Boknis Eck are a source of ammonium (Dale et al., 2011), which also shows in bottom water concentrations (Fig. 2). As oxygen is still abundant, this ammonium can potentially be oxidized to nitrite and nitrate by nitrifying microorganisms. We did not measure ammonium isotope signatures in the water column, but assuming that remineralization does not coincide with significant fractionation (Kendall, 1998; Lehmann et al., 2004), the isotope value of surface sediments should be transferred to ammonium. Sediments in the Kattegat region have a $\delta^{15} \mathrm{~N}$ of $\approx 7 \%$ o (Voss et al., 2005). Assuming this value for dissolved ammonium, nitrification should produce isotopically lighter nitrate, as the fractionation factor for ammonium oxidation ranges between 14 and $35 \%$ (Casciotti et al., 2003). Thus, this appears like an unlikely explanation of the relatively heavy isotope values, as it would also require the sediments to be a net nitrate source, which is improbable in Boknis Eck sediments (cf. Dale et al., 2011).

If this water column nitrate on the other hand is influenced by the fractionation occurring during sedimentary denitrification, the water should be relatively enriched in $\delta^{15} \mathrm{~N}_{\mathrm{NO}_{3}}$. Bottom water nitrate in April has a $\delta^{15} \mathrm{~N}_{\mathrm{NO}_{3}}$ of $7.7 \%$, and while this is derived from a single measurement and thus is a tentative result, it points towards a contribution of enriched nitrate to the total pool, elevating $\delta^{15} \mathrm{~N}_{\mathrm{NO}_{3}}$ both above the marine background of $5 \%$ and depleted isotope values $\ll 7 \%$ as we might expect them from nitrification of ammonium. The high $\delta^{18} \mathrm{O}_{\mathrm{NO}_{3}}$ value (13.5\% in bottom water) also suggests that a fractionating process impacted bottom 
water nitrate. Such enrichment cannot be explained by nitrification, because during nitrification, five out of six, if not more, oxygen atoms in freshly produced nitrate stem from ambient water (Casciotti et al., 2002). This water has a relatively low $\delta^{18} \mathrm{O}$ value of, depending on the influence of freshwater, $0 \%$ or less (Harwood et al., 2008). One oxygen atom can derive from dissolved $\mathrm{O}_{2}$, which has a $\delta^{18} \mathrm{O}$ of $23.5 \%$ (Kroopnick and Craig, 1972). The weighted average of these sources yields an isotope value far below the observed $13.5 \%$ of $\delta^{18} \mathrm{O}_{\mathrm{NO}_{3}}$. Hence, it is implausible that this relatively enriched oxygen value of nitrate can be derived directly from nitrification.

\subsection{Coupling of nitrite and nitrate isotope effects}

Throughout our experiment, the nitrite concentration remained constant, and there was no intermediate nitrite accumulation (Fig. 3a). Despite these static concentrations, $\delta{ }^{15} \mathrm{~N}_{\mathrm{NO}_{2}}$ changed rapidly and followed $\delta^{15} \mathrm{~N}_{\mathrm{NO}_{3}}$ very closely. This proves that nitrite is an active intermediate in dissimilation, and that we did not measure a refractory nitrite pool that was below the threshold for bacterial uptake. It is evident that nitrate and subsequent nitrite reduction are closely coupled, as isotope values of nitrite closely follow that of nitrate throughout the incubation.

The calculated $\varepsilon^{15}$ values for nitrite and nitrate are almost identical, which is also influenced by calculating $\varepsilon^{15} \mathrm{NO}_{2}$ on the basis of the remaining nitrate concentration. Nevertheless, if there were no fractionation apart from that coupled to nitrate reduction involved between extracellular nitrate and nitrite, the difference between $\delta^{15} \mathrm{~N}_{\mathrm{NO}_{3}}$ and $\delta^{15} \mathrm{~N}_{\mathrm{NO}_{2}}$ should equal the inferred value of $\varepsilon^{15} \mathrm{~N}_{\mathrm{NO}_{3}}$. Surprisingly, this is not the case: $\delta^{15} \mathrm{~N}_{\mathrm{NO}_{3}}-\delta^{15} \mathrm{~N}_{\mathrm{NO}_{2}}$ is consistently lower than the nitrate fractionation factor derived from the Rayleigh plot (Fig. 4), 14.2 $\pm 1.3 \%$ o compared to $\varepsilon^{15} \mathrm{~N}_{\mathrm{NO}_{3}}=18.9 \%$ (average of both incubations), leaving a difference of 4-5\%o.

Reasons for this discrepancy may lie in the molecular basis of denitrification in the denitrifying cells. Denitrifiers are a polyphyletic group (e.g., Zumft, 1997; Thamdrup and Dalsgaard, 2008), but mostly belonging to the Gram-negative Proteobacteria. For simplicity, we will thus restrict the discussion on the impact of intracellular transport and turnover to this group (see Fig. 6). During denitrification, the first step is the uptake of nitrate across the cell wall into the cytoplasm, because the respiratory nitrate reductase Nar, which catalyzes the first step of denitrification, is an integral membrane protein with its active site directed towards the cytoplasm. After reduction, nitrite has to be transported out of the cell into the periplasm, where the nitrite reductase (Nir) is located (Wunderlich et al., 2012; Zumft, 1997). Additionally, denitrifiers can also possess a second nitrate reducing enzyme, the periplasmic Nap, but this enzyme is not involved in energy conservation, as it does not translocate protons across the inner membrane. As discussed previously, Granger et al. (2008) speculated that an involvement of Nap in nitrate reduction in denitrifiers might lower the observed isotope effect. However, classical denitrifiers generally seem to rely on nitrate reduction by Nar, with little contribution of Nap during anaerobic growth (Moreno-Vivián et al., 1999; Shapleigh, 2006).

We will accordingly explore two hypotheses for the intriguing difference between the Rayleigh fractionation factor of nitrate and $\left(\delta^{15} \mathrm{~N}_{\mathrm{NO}_{3}}-\delta^{15} \mathrm{~N}_{\mathrm{NO}_{2}}\right)$ : (1) reversibility of nitrate reduction on the enzyme level and (2) further fractionation during nitrite processing.

\subsubsection{Reversibility of nitrate reduction}

Within the cytoplasm, nitrate is reduced to nitrite, and the difference in isotope values of intracellular nitrate and nitrite should correspond to the enzyme-level isotope effect of Nar, for example, $19 \%$. During re-oxidation of nitrite, inverse isotope fractionation occurs (Casciotti, 2009), so nitrate, the substrate of Nar, would become more enriched as the reaction proceeds, producing less depleted nitrite than without reoxidation. While studies addressing this fractionator during re-oxidation refer to natural environments, the same mechanisms might apply for reverse reactions on the enzyme level. Such intracellular re-oxidation of nitrite would lower the offset between nitrite and extracellular nitrate, so it would, from a mathematical point of view, explain our data nicely.

Unfortunately, there is no evidence of reversibility of nitrate reduction denitrification on a cellular level. Nitrite exchanges oxygen atoms with ambient water, so any reoxidation should be visible in oxygen atoms in nitrite. Different recent studies (Knöller et al., 2011; Wunderlich et al., 2012) closely investigated the potential for nitrite reoxidation, and concur that there is no re-oxidation of nitrite during dissimilatory nitrate reduction within bacterial cells under anoxic conditions.

\subsubsection{Fractionation during nitrite processing?}

Another explanation of the unexpected offset between nitrite and nitrate isotope values is that further fractionation occurs during denitrification, i.e., that nitrite is subject to another independent fractionation factor within the cell. We will evaluate this option based on individual process rates within the cell.

At the beginning of the reaction, nitrate is actively transported into the cell ( $k_{1}$ in Fig. 6), and the loss rate of nitrate back out of the cell is assumed to be much lower (i.e., $k_{1} \gg$ $k_{-1}$, cf. Granger et al., 2008; Wunderlich et al., 2012). Within the cytoplasm, nitrate is reduced by Nar at rate $k_{2}$, assumingly with an isotope effect of $\sim 19 \%$ o. Accordingly, the initially produced intracellular nitrite should have an isotope value that is $19 \%$ o below that of nitrate. For further reduction, nitrite will now be actively transported to the periplasm, where it is reduced to NO by Nir. Both processes, export to the periplasm and nitrite reduction rate, are controlled via 


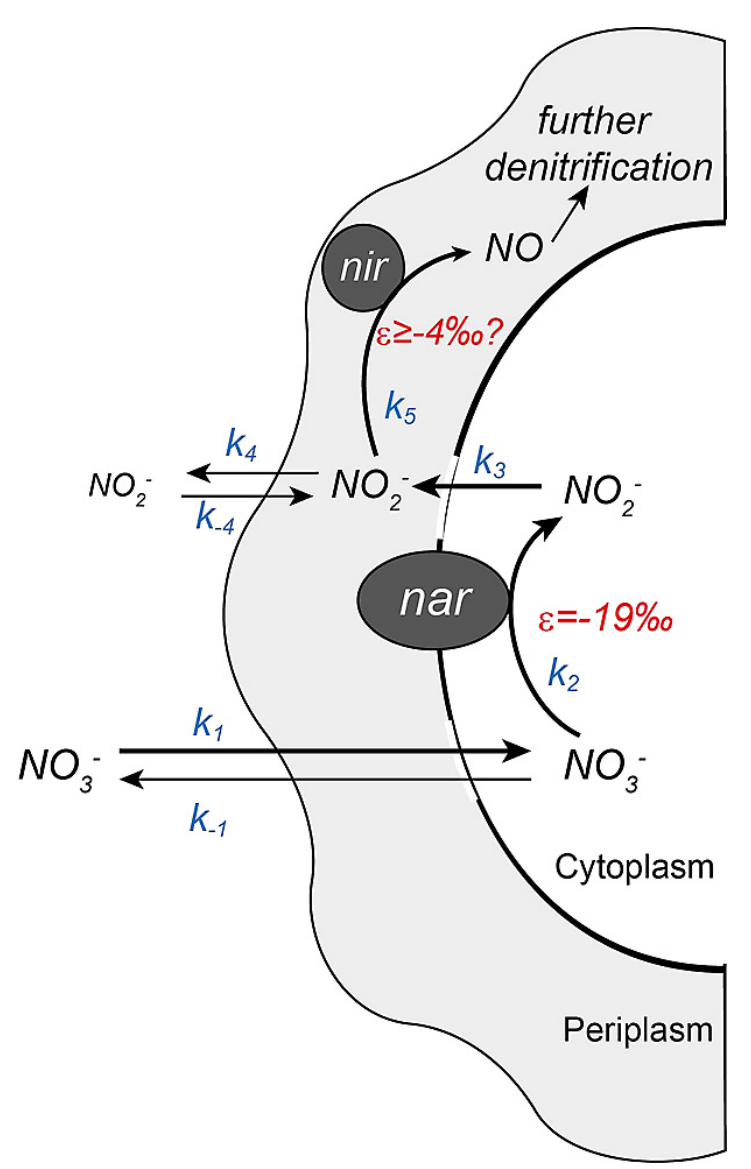

Fig. 6. Illustration of nitrate and nitrite reduction enzymes and their orientation across the bacterial membrane. For the sake of clarity, nitrate ad- and desorption to and from the outer membrane are not shown (see Sect. 4.4, for details).

activity of a NarK-type transporter protein (Moir and Wood, 2001; Zumft, 1997) and Nir activity, respectively. A stable equilibrium between both reactions (i.e., the rates $k_{3}$ and $k_{5}$ ) could theoretically explain the constant isotope offset: if the fraction of exported vs. reduced nitrite remains constant, the same holds for the fraction of substrate versus the original concentration resulting in a constant value for $\ln (f)$. This might produce a constant isotope offset as we see it in our experiment.

However, no nitrite was accumulated in our incubations, pointing towards very rapid uptake of freshly produced nitrite. $k_{4}$ and $k_{-4}$ are obviously identical, and the turnover rate $k_{5}$ will be much faster than the loss rate $k_{4}$. The dynamic change of $\delta^{15} \mathrm{~N}_{\mathrm{NO}_{2}}$ in contrast to concentration during the experiment shows that some nitrite does escape from the cell, but it is apparently continuously taken up again ( $k_{4}$ and $k_{-4}$ in Fig. 6), preventing intermediate nitrite accumulation. If this small amount of nitrite escaping from the periplasm had such a large effect on isotope signatures of external nitrite, the intrinsic fractionation would need to be large, and this is rather unlikely. Given that nitrite reduction apparently occurs at a much higher rate than the turnover of nitrite $\left(k_{5} \gg k_{4}\right)$, we conclude that the offset is most likely due to a delayed response of the extracellular nitrite pool: the import/export does not keep track with the much faster internal processing of nitrate and nitrite. This scenario explains both the nitrate and the nitrite isotope data in our incubation, and needs to be kept in mind in further investigations that aim to address the specific isotope effect of individual reduction steps. Hopefully, further analytical advances will permit a more detailed analysis of these intermediates and isotope fractionation during individual steps of denitrification, adding further evidence to our data.

\section{Conclusions}

This study of isotope changes during denitrification confirmed that isotope fractionation during nitrate reduction coincides with a comparable fractionation as water column denitrification, and that this is not merely characteristic of deepsea sites with relatively low reactivity, but also of coastal sites that receive significant amounts of organic matter, which can fuel denitrification. Concomitant analysis of nitrate isotope values in bottom water showed that nitrate is enriched over the marine background value. This cannot be explained by nitrate production via nitrification alone, because ammonium is abundant and the associated fractionation should lower nitrate isotope values. These data provide first evidence that the current view of sedimentary denitrification having little to no impact on water column nitrate isotope values might need to be re-evaluated, which is an exciting area for future studies.

Apart from these tentative first data, our experiment allowed some conclusions on intracellular processing during denitrification. We measured isotope values of both substrate and first intermediate of denitrification, nitrate and nitrite, and find an offset between the respective isotope values. We attribute this to a delayed response of the extracellular nitrite pool due to rapid turnover within the cell, which has previously been overlooked due to analytical limitations.

Acknowledgements. The authors thank Niko Finke for technical advice and highly appreciated help with sediment sampling on board the Alkor, and Tina Treude for access to labs at Geomar and the Alkor. We would also like to thank the captain and crew of R/V Alkor and Hermann Bange for helpful background information and valuable scientific discussions on Boknis Eck. We thank Susanna Hietanen and an anonymous reviewer for constructive comments that improved this manuscript.

This study was partly funded by the Danish National Research Foundation; K. D. was funded by the German Research Foundation (DA 1207/1-1).

Edited by: H. Bange 


\section{References}

Alkhatib, M., Lehmann, M. F., and del Giorgio, P. A.: The nitrogen isotope effect of benthic remineralization-nitrificationdenitrification coupling in an estuarine environment, Biogeosciences, 9, 1633-1646, doi:10.5194/bg-9-1633-2012, 2012.

Altabet, M. A.: Constraints on oceanic $\mathrm{N}$ balance/imbalance from sedimentary ${ }^{15} \mathrm{~N}$ records, Biogeosciences, 4, 75-86, doi:10.5194/bg-4-75-2007, 2007.

Altabet, M. A., Higginson, M. J., and Murray, D. W.: The effect of millennial-scale changes in Arabian Sea denitrification on atmospheric $\mathrm{CO}_{2}$, Nature, 415, 159-162, 2002.

Bange, H. W., Hansen, H. P., Malien, F., Laß, K., Karstensen, J., Petereit, C., Friedrichs, G., and Dale, A. W.: Boknis Eck Time Series Station (SW Baltic Sea): Measurements from 1957 to 2010, LOICZ Inprint, 2011/1, 16-22, 2011.

Berner, R. A.: Early Diagenesis: A Theoretical Approach, Princeton University Press, Princeton, 241 pp., 1980.

Böhlke, J. K., Mroczkowski, S. J., and Coplen, T. B.: Oxygen isotopes in nitrate: new reference materials for O-18 : O-17 : O-16 measurements and observations on nitratewater equilibration, Rapid Commun. Mass Sp., 17, 1835-1846, doi:10.1002/rcm.1123, 2003.

Böhlke, J. K., Smith, R. L., and Hannon, J. E.: Isotopic analysis of $\mathrm{N}$ and $\mathrm{O}$ in nitrite and nitrate by sequential selective bacterial reduction to $\mathrm{N}_{2} \mathrm{O}$, Anal. Chem., 79, 5888-5895, 2007.

Braman, R. S. and Hendrix, S. A.: Nanogram nitrite and nitrate determination in environmental and biological materials by Vanadium (III) reduction with chemiluminiscence detection, Anal. Chem., 61, 2715-2718, doi:10.1021/ac00199a007, 1989.

Brandes, J. A. and Devol, A. H.: A global marine-fixed nitrogen isotopic budget: Implications for Holocene nitrogen cycling, Global Biogeochem. Cy., 16, 1120, doi:10.1029/2001GB001856, 2002.

Brandes, J. A., Devol, A. H., Yoshinari, T., Jayakumar, D. A., and Naqvi, S. W. A.: Isotopic composition of nitrate in the central Arabian Sea and eastern tropical North Pacific: A tracer for mixing and nitrogen cycles, Limnol. Oceanogr., 43, 1680-1689, 1998.

Casciotti, K. L.: Inverse kinetic isotope fractionation during bacterial nitrite oxidation, Geochim. Cosmochim. Ac., 73, 2061-2076, 2009.

Casciotti, K. L., Sigman, D. M., Hastings, M. G., Böhlke, J. K., and Hilkert, A.: Measurement of the oxygen isotopic composition of nitrate in seawater and freshwater using the denitrifier method, Anal. Chem., 74, 4905-4912, 2002.

Casciotti, K. L., Sigman, D. M., and Ward, B. B.: Linking diversity and stable isotope fractionation in ammonia-oxidizing bacteria, Geomicrobiol. J., 20, 335-353, 2003.

Casciotti, K. L., Böhlke, J. K., McIlvin, M. R., Mroczkowski, S. J., and Hannon, J. E.: Oxygen isotopes in nitrite: Analysis, calibration, and equilibration, Anal. Chem., 79, 2427-2436, 2007.

Dale, A. W., Sommer, S., Bohlen, L., Treude, T., Bertics, V. J., Bange, H. W., Pfannkuche, O., Schorp, T., Mattsdotter, M., and Wallmann, K.: Rates and regulation of nitrogen cycling in seasonally hypoxic sediments during winter (Boknis Eck, SW Baltic Sea): Sensitivity to environmental variables, Estuar. Coast. Shelf Sci., 95, 14-28, doi:10.1016/j.ecss.2011.05.016, 2011.

Dalsgaard, T., Thamdrup, B., and Canfield, D. E.: Anaerobic ammonium oxidation (anammox) in the marine environment, Res. Microbiol., 156, 457-464, 2005.
Delwiche, C. C. and Steyn, P. L.: Nitrogen isotope fractionation in soils and microbial reactions, Environ. Sci. Technol., 4, 929-935, doi:10.1021/es60046a004, 1970.

Emeis, K. C., Mara, P., Schlarbaum, T., Mobius, J., Dähnke, K., Struck, U., Mihalopoulos, N., and Krom, M.: External N inputs and internal $\mathrm{N}$ cycling traced by isotope ratios of nitrate, dissolved reduced nitrogen, and particulate nitrogen in the eastern Mediterranean Sea, J. Geophys. Res.-Biogeo., 115, G04041, doi:10.1029/2009jg001214, 2010.

Galloway, J. N., Dentener, F. J., Capone, D. G., Boyer, E. W., Howarth, R. W., Seitzinger, S. P., Asner, G. P., Cleveland, C. C., Green, P. A., Holland, E. A., Karl, D. M., Michaels, A. F., Porter, J. H., Townsend, A. R., and Vorosmarty, C. J.: Nitrogen cycles: past, present, and future, Biogeochemistry, 70, 153-226, 2004.

Granger, J., Sigman, D. M., Lehmann, M. F., and Tortell, P. D.: Nitrogen and oxygen isotope fractionation during dissimilatory nitrate reduction by denitrifying bacteria, Limnol. Oceanogr., 53, 2533-2545, 2008.

Grasshoff, K., Ehrhardt, M., and Kremling, K. (Eds.): Methods of Seawater Analysis, 3rd edition, Verlag Chemie, Weinheim, 1999.

Gruber, N.: The dynamics of the marine nitrogen cycle and its influence on atmospheric $\mathrm{CO}_{2}$ variation, in: Carbon Climate Interactions, edited by: Follows, M. and Oguz, T., J. Wiley, Hoboken, NJ, 99-148, 2004.

Hall, P. O. and Aller, R. C.: Rapid, Small-Volume, Flow-Injection Analysis for Sigma- $\mathrm{CO}_{2}$ and $\mathrm{NH}_{4}^{+}$in Marine and Fresh-Waters, Limnol. Oceanogr., 37, 1113-1119, 1992.

Harwood, A. J. P., Dennis, P. F., Marca, A. D., Pilling, G. M., and Millner, R. S.: The oxygen isotope composition of water masses within the North Sea, Estuar. Coast. Shelf Sci., 78, 353-359, 2008.

Kendall, C.: Tracing nitrogen sources and cycling in catchments, in: Isotope Tracers in Catchment Hydrology, edited by: Kendall, C. and McDonnell, J. J., Elsevier, Amsterdam, 521-576, 1998.

Knöller, K., Vogt, C., Haupt, M., Feisthauer, S., and Richnow, H. H.: Experimental investigation of nitrogen and oxygen isotope fractionation in nitrate and nitrite during denitrification, Biogeochemistry, 103, 371-384, doi:10.1007/s10533-010-9483-9, 2011.

Kroopnick, P. and Craig, H.: Atmospheric Oxygen - Isotopic Composition and Solubility Fractionation, Science, 175, 54-55, 1972.

Lehmann, M. F., Reichert, P., Bernasconi, S. M., Barbieri, A., and McKenzie, J. A.: Modelling nitrogen and oxygen isotope fractionation during denitrification in a lacustrine redox-transition zone, Geochim. Cosmochimica Ac., 67, 2529-2542, 2003.

Lehmann, M. F., Sigman, D. M., and Berelson, W. M.: Coupling the ${ }^{15} \mathrm{~N} /{ }^{14} \mathrm{~N}$ and ${ }^{18} \mathrm{O} /{ }^{16} \mathrm{O}$ of nitrate as a constraint on benthic nitrogen cycling, Mar. Chem., 88, 1-20, 2004.

Lehmann, M. F., Sigman, D. M., McCorkle, D. C., Granger, J., Hoffmann, S., Cane, G., and Brunelle, B. G.: The distribution of nitrate ${ }^{15} \mathrm{~N} /{ }^{14} \mathrm{~N}$ in marine sediments and the impact of benthic nitrogen loss on the isotopic composition of oceanic nitrate, Geochim. Cosmochim. Ac., 71, 5384-5404, 2007.

Mackin, J. E. and Aller, R. C.: Ammonium adsorption in marine sediments, Limnol. Oceanogr., 29, 250-257, 1984.

Mariotti, A., Germon, J. C., Hubert, P., Kaiser, P., Letolle, R., Tardieux, A., and Tardieux, P.: Experimental-Determination of Nitrogen Kinetic Isotope Fractionation - Some Principles - Illustration for the Denitrification and Nitrification Processes, Plant 
Soil, 62, 413-430, 1981.

Moir, J. W. B. and Wood, N. J.: Nitrate and nitrite transport in bacteria, Cell. Mol. Life Sci., 58, 215-224, doi:10.1007/p100000849, 2001.

Montoya, J. P., Carpenter, E. J., and Capone, D. G.: Nitrogen fixation and nitrogen isotope abundances in zooplankton of the oligotrophic North Atlantic, Limnol. Oceanogr., 47, 1617-1628, 2002.

Moreno-Vivián, C., Cabello, P., Martínez-Luque, M., and Castillo, F.: Prokaryotic Nitrate Reduction: Molecular Properties and Functional Distinction among Bacterial Nitrate Reductases, Bacteriology, 181, 6573-6584, 1999.

Naqvi, S. W. A., Yoshinari, T., Brandes, J. A., Devol, A. H., Jayakumar, D. A., Narvekar, P. V., Altabet, M. A., and Codispoti, L. A.: Nitrogen isotopic studies in the suboxic Arabian Sea, P. Indian AS-Earth, 107, 367-378, 1998.

Naqvi, S. W. A., Naik, H., Pratihary, A., D’Souza, W., Narvekar, P. V., Jayakumar, D. A., Devol, A. H., Yoshinari, T., and Saino, T.: Coastal versus open-ocean denitrification in the Arabian Sea, Biogeosciences, 3, 621-633, doi:10.5194/bg-3-621-2006, 2006.

Nittrouer, C. A., Lopez, G. R., Wright, L. D., Bentley, S. J., D'Andrea, A. F., Friedrichs, C. T., Craig, N. I., and Sommerfield, C. K.: Oceanographic processes and the preservation of sedimentary structure in Eckernforde Bay, Baltic Sea, Cont. Shelf Res., 18, 1689-1714, 1998.

Orsi, T. H., Werner, F., Milkert, D., Anderson, A. L., and Bryant, W. R.: Environmental overview of Eckernforde Bay, northern Germany, Geo-Mar. Lett., 16, 140-147, doi:10.1007/bf01204501, 1996.

Prokopenko, M. G., Sigman, D. M., Berelson, W. M., Hammond, D. E., Barnett, B., Chong, L., and Townsend-Small, A.: Denitrification in anoxic sediments supported by biological nitrate transport, Geochim. Cosmochim. Ac., 75, 7180-7199, doi:10.1016/j.gca.2011.09.023, 2011.

Seitzinger, S., Harrison, J. A., Böhlke, J. K., Bouwman, A. F., Lowrance, R., Peterson, B., Tobias, C., and Van Drecht, G.: Denitrification across landscapes and waterscapes: A synthesis, Ecol. Appl., 16, 2064-2090, 2006.

Shapleigh, J. P.: The denitrifying prokaryotes, in: The Prokaryotes, 3 Edn., edited by: Dworkin, M., Falkow, S., Rosenberg, E. I., Schleifer, K.-H., and Stackebrandt, E., Springer, New York, 769792, 2006.

Sigman, D. M., Altabet, M. A., McCorkle, D. C., Francois, R., and Fischer, G.: The delta ${ }^{15} \mathrm{~N}$ of nitrate in the Southern Ocean: Nitrogen cycling and circulation in the ocean interior, J. Geophys. Res.-Oceans, 105, 19599-19614, 2000.

Sigman, D. M., Casciotti, K. L., Andreani, M., Barford, C., Galanter, M., and Böhlke, J. K.: A bacterial method for the nitrogen isotopic analysis of nitrate in seawater and freshwater, Anal. Chem., 73, 4145-4153, 2001.

Sigman, D. M., Granger, J., DiFiore, P. J., Lehmann, M. M., Ho, R., Cane, G., and van Geen, A.: Coupled nitrogen and oxygen isotope measurements of nitrate along the eastern North Pacific margin, Global Biogeochem. Cy., 19, 4022, doi:10.1029/2005GB002458, 2005.
Sigman, D. M., DiFiore, P. J., Hain, M. P., Deutsch, C., Wang, Y., Karl, D. M., Knapp, A. N., Lehmann, M. F., and Pantoja, S.: The dual isotopes of deep nitrate as a constraint on the cycle and budget of oceanic fixed nitrogen, Deep-Sea Res. Pt. I, 56, 14191439, doi:10.1016/j.dsr.2009.04.007, 2009.

Thamdrup, B.: New Pathways and processes in the global nitrogen cycle, Annu. Rev. Ecol. Evol. S., 43, 407-428, doi:10.1146/annurev-ecolsys-102710-145048, 2012.

Thamdrup, B. and Dalsgaard, T.: Production of N-2 through anaerobic ammonium oxidation coupled to nitrate reduction in marine sediments, Appl. Environ. Microb., 68, 1312-1318, 2002.

Thamdrup, B. and Dalsgaard, T.: Nitrogen Cycling in Sediments, in: Microbial Ecology of the Oceans, 2 Edn., edited by: Kirchman, D. L., John Wiley \& Sons, Inc., 527-568, 2008.

Treude, T., Krüger, M., Boetius, A., and Jorgensen, B. B.: Environmental control on anaerobic oxidation of methane in the gassy sediments of Eckernförde Bay (German Baltic), Limnol. Oceanogr., 50, 1771-1786, 2005.

Trimmer, M. and Engström, P.: Distribution, activity, and ecology of anammox bacteria in aquatic environments, in: Nitrification, edited by: Ward, B. B., Arp, D. J., and Klotz, M. G., ASM Press, Washington DC, 2011.

Trimmer, M., Nicholls, J. C., and Deflandre, B.: Anaerobic Ammonium Oxidation Measured in Sediments along the Thames Estuary, United Kingdom, Appl. Environ. Microb., 69, 6447-6454, doi:10.1128/aem.69.11.6447-6454.2003, 2003.

Voss, M. and Montoya, J. P.: Nitrogen Cycle: Oceans apart, Nature, 461, 49-50, doi:10.1038/461049a, 2009.

Voss, M., Dippner, J. W., and Montoya, J. P.: Nitrogen isotope patterns in the oxygen-deficient waters of the Eastern Tropical North Pacific Ocean, Deep-Sea Res. Pt. I, 48, 1905-1921, 2001.

Voss, M., Emeis, K. C., Hille, S., Neumann, T., and Dippner, J. W.: Nitrogen cycle of the Baltic Sea from an isotopic perspective, Global Biogeochem. Cy., 19, B3001, doi:10.1029/2004GB002338, 2005.

Wankel, S. D., Kendall, C., and Paytan, A.: Using nitrate dual isotopic composition (delta ${ }^{15} \mathrm{~N}$ and delta ${ }^{18} \mathrm{O}$ ) as a tool for exploring sources and cycling of nitrate in an estuarine system: Elkhorn Slough, California, J. Geophys. Res.-Biogeo., 114, G01011, doi:10.1029/2008jg000729, 2009.

Whiticar, M. J.: Diagenetic relationships of methanogenesis, nutrients, acoustic turbidity, pockmarks and freshwater seepages in Eckernförde Bay, Mar. Geol., 182, 29-53, doi:10.1016/s00253227(01)00227-4, 2002.

Wunderlich, A., Meckenstock, R., and Einsiedl, F.: Effect of Different Carbon Substrates on Nitrate Stable Isotope Fractionation During Microbial Denitrification, Environ. Sci. Technol., 46, 4861-4868, doi:10.1021/es204075b, 2012.

Zumft, W. G.: Cell Biology and Molecular Basis of Denitrification, Microbiol. Mol. Rev., 61, 533-616, 1997. 